\title{
DAYA SAING BERAS PANDANWANGI, BERAS MERAH DAN BERAS HITAM DI WILAYAH PEMASARAN KABUPATEN CIANJUR
}

\author{
Oleh: \\ Endah Lisarini $* *$ ) \\ Adam Abdurahman *)
}

\begin{abstract}
Abstrak
Pemerintah Indonesia melalui Kementerian Pertanian telah melakukan klasifikasi kelas mutu beras yang dituangkan dalam Peraturan Menteri Pertanian Nomor 31/PERMENTAN//PP.130/8/2017. Kelas mutu beas yang ditetapkan adalah kelas mutu beras medium, premium dan khusus. Beras yang dimasukkan ke dalam kelas mutu beras khusus antara lain adalah beras Indikasi Geografis, beras organik, beras kesehatan dan beras yang tidak dapat diproduksi di dalam negeri. Cianjur merupakan salah satu wilayah yang menghasilkan beras Indikasi Geografis yaitu beras Pandanwangi. Cianjur juga dikenal sebagai sentra produksi beras merah dan hitam yang dikenal sebagai beras kesehatan. Penelitian ini dilakukan untuk mengkaji : 1) Tingkat daya saing beras Pandanwangi, beras merah dan beras hitam; 2) Perbedaan signifikan tingkat daya saing antara beras Pandanwangi, beras merah dan beras hitam. Data tanggapan mengenai faktor-faktor yang menentukan tingkat daya saing ketiga jenis beras diperoleh dari 30 responden sebagai sampel penelitian. Sampel diambil dengan teknik non probability quota sampling dari populasi petani produsen dan pengecer beras yang ada di wilayah pemasaran beras Cianjur. Untuk menjawab tujuan penelitian pertama yaitu mengetahui tingkat daya saing, dilakukan pengkategorian kelas tingkat daya saing. Analisis dan pembahasan dilakukan secara deskriptif. Sedangkan untuk menjawab tujuan penelitian ke dua, dilakukan pengujian hipotesis dengan uji T. Uji T digunakan untuk mengetahui signifikansi perbedaan daya saing antara beras Pandanwangi terhadap beras merah, beras Pandanwangi terhadap beras hitam dan antara beras hitam dengan beras merah. Hasil penelitian menunjukkan : 1) Tingkat daya saing antara beras Pandanwangi, beras merah dan beras hitam dari segi kualitas, harga dan ketersediaan berdasarkan tanggapan responden didapatkan bahwa tingkat daya saing tertinggi sampai dengan terendah berturut-turut adalah beras Pandanwangi, beras merah dan terakhir beras hitam. Nilai skor rata-rata tanggapan responden berturut-turut sebesar 4.02, 3.11 dan 2.97. 2) Dari hasil uji T diketahui bahwa tidak terdapat perbedaan tingkat daya saing yang signifikan dalam hal kualitas, harga dan ketersediaan baik antara beras pandanwangi dengan beras merah, antara beras Pandanwangi dengan beras hitam dan antara beras merah dengan beras hitam
\end{abstract}

Kata kunci : daya saing, beras Pandanwangi, beras khusus

\begin{abstract}
The Indonesian government through the Ministry of Agriculture has carried out the classification of rice quality classes as outlined in the Minister of Agriculture Regulation No. 31 / PERMENTAN // PP.130 / 8/2017. The beas quality class is defined as medium, premium and special rice quality classes. Rice included in special rice quality classes includes rice Geographical Indications, organic rice, health rice and rice that cannot be produced domestically. Cianjur is one of the areas that produces Geographical Indication rice, Pandanwangi rice. Cianjur is also known as a center of red and black rice production known as health rice. This research was conducted to examine: 1) the level of competitiveness of Pandanwangi rice, brown rice and black rice; 2) Significant difference in competitiveness between Pandanwangi rice, brown rice and black rice. Response data regarding the factors that determine the level of competitiveness of the three types of rice
\end{abstract}


were obtained from 30 respondents as research samples. The sample was taken with non probability quota sampling technique from the population of rice producers and retailers in the Cianjur rice marketing area. To answer the purpose of the first research, namely to know the level of competitiveness, classifications of competitiveness levels were carried out. Analysis and discussion are carried out descriptively. Meanwhile, to answer the purpose of the second study, the hypothesis was tested by the T test. T test was used to determine the significance of differences in competitiveness between Pandanwangi rice with brown rice, Pandanwangi rice with black rice and black rice with brown rice. The results showed: 1) The level of competitiveness between Pandanwangi rice, brown rice and black rice in terms of quality, price and availability based on respondents' responses found that the highest level of competitiveness to the lowest in a row was Pandanwangi rice, brown rice and finally black rice. The average score of respondents' responses was 4.02, 3.11 and 2.97, respectively. 2) From the results of the $T$ test it is known that there is no significant difference in the level of competitiveness in terms of quality, price and good availability between pandanwangi rice and brown rice, between Pandanwangi rice and black rice and between brown rice and black rice

Key words : competitiveness, Pandanwangi rice, special rice

*) Alumni Fakultas Sains Terapan UNSUR

**) Dosen Fakultas Sains Terapan UNSUR 


\section{PENDAHULUAN}

Hingga saat ini kedudukan beras sebagai makanan pokok utama bagi sebagian besar penduduk Indonesia belum tergantikan. Konsumsi beras per kapita sekira lebih dari 90\% penduduk Indonesia sebesar $130 \mathrm{~kg}$ per tahun (Saragih dalam Purwono, 2013; Mohanty dalam David, 2015). Berbagai upaya untuk meningkatkan produksi beras dan perbaikan sistem pemasarannya terus dilakukan oleh semua pihak terkait termasuk pemerintah. Sejumlah kebijakan pemerintah yang mendukung kemandirian pangan (UU No.18, 2012; Perda Jabar No.4, 2012), yang berhubungan dengan pengaturan distribusi beras, yang berkaitan dengan penetapan harga hingga yang mengatur pengelompokan kelas beraspun sudah diadakan. Peraturan Menteri Pertanian Nomor 31/PERMENTAN//PP.130/8/2017 tentang kelas mutu beras mengatur pengkelasan beras. Dinyatakan dalam permentan tersebut terdapat kelas mutu beras medium dan premium (Pasal 1 ayat 2) dan kelas mutu beras khusus (Pasal 2 ayat 1). Yang termasuk kelas mutu beras khusus antara lain beras merah, beras hitam dan beras ketan (Pasal 2 ayat 2).

Bagi sebagian besar konsumen beras terutama yang tergolong keluarga pra sejahtera hingga sejahtera II (BKKBN, 2012), mengkonsumsi beras adalah untuk pemenuhan kebutuhan pangan semata. Sementara itu bagi keluarga sejahtera III dan III plus (BKKBN 2012), mengkonsumsi beras tidak hanya untuk pemenuhan pangan saja melainkan juga untuk mempertahankan kualitas kesehatannya. Oleh karena itu, beras yang dikonsumsinya merupakan beras yang memenuhi kriteria tertentu baik menurut anggapan konsumen maupun menurut Standar Nasional Indonesia (SNI) untuk produk beras. Konsumen menganggap beras sehat adalah beras yang tidak tercampur dengan bahan-bahan tambahan yang membahayakan kesehatan seperti pemutih, penguat aroma dan bahan lainnya yang ditujukan untuk menarik

Daya Saing Beras Pandanwangi, Beras Merah Dan Beras Hitam Di Wilayah Pemasaran Kabupaten Cianjur minat konsumen. Sebaliknya produsen beras yang terdiri dari petani, pedagang atau pengecer beras akan lebih menyukai memproduksi dan menjual beras yang banyak diminati oleh konsumen. Penjual beras di Cianjur umumnya menawarkan lebih dari satu macam jenis beras. Beras Cianjuran atau beras yang berasal dari Cianjur yang banyak ditawarkan. Di antara beras Cianjur, terdapat tiga jenis beras yang banyak dicari konsumen yaitu beras Pandanwangi, beras merah dan beras hitam. Beragam alasan konsumen memutuskan membeli salah satu dari beras Pandanwangi,beras merah dan beras hitam. Ketiga jenis beras tersebut juga termasuk ke dalam kelas mutu beras khusus.

Walaupun ketiga jenis beras tersebut di atas masuk ke dalam kelas mutu beras yang sama yaitu mutu kelas beras khusus, namun memiliki karakteristik yang berbeda. Peminat dari masing-masing beras itupun berbeda. Oleh karena itu, daya saing untuk merebut minat konsumen dari ketiga jenis beras itupun berbeda. Berdasarkan paparan di atas, dilakukanlah penelitian dengan tujuan untuk mengkaji : 1) tingkat daya saing beras Pandanwangi terhadap beras merah dan beras hitam; 2) perbedaan tingkat daya saing beras Pandanwangi dengan beras merah dan beras hitam. Diharapkan hasil penelitian ini dapat lebih mengenalkan kepada masyarakat konsumen mengenai beras Pandanwangi, beras merah dan beras hitam terutama dari segi keberadaan dan manfaatnya. Pada akhirnya konsumen dapat ikut berkontribusi dalam pengawasan kemurnian beras - beras tersebut sebagai beras khusus yang memiliki keunggulan khusus pula.

\section{TINJAUAN PUSTAKA}

Beras Pandanwangi merupakan salah satu jenis beras di Indonesia yang sudah mendapatkan Sertifikat Indikasi Geografis (SIG) dari Kementerian Hukum dan HAM RI tahun 2014. 
Pandanwangi merupakan beras lokal Cianjur yang sudah populer akan aroma khas dan kepulenannya. Karakteristik botani Pandanwangi yang membedakannya dengan tanaman padi lainnya adalah tinggi tanaman yang mencapai $150 \mathrm{~cm}$ dan berumur panjang sekira 155 hari serta nilai jual yang lebih tinggi dibandingkan dengan beras Cianjur lainnya (Dinas Pertanian Kabupaten Cianjur, 2009; MP3C, 2015). Beras Merah merupakan beras yang dihasilkan dari padi beras merah yang memiliki banyak keunggulan di antaranya kandungan gizi yang tinggi dan memiliki harga jual yang tinggi dibanding beras putih (Asmarani, 2017) dan dikelompokkan ke kelas mutu beras khusus karena termasuk beras kesehatan (PERMENTAN, 2017). Beras hitam merupakan beras yang dihasilkan dari jenis padi hitam yang umur panennya cukup lama dibanding padi putih (Sa `adah, I.R. dkk, 2016). Sementara menurut Tan dkk (2016) bahwa beras hitam (Oriza Satifa. L) memiliki kandungan gizi yang lebih unggul diabndingkan jenis beras lainnya. Masa panen yang cukup lama pada jenis padi hitam menjadikan minat petani enggan menanam jenis padi hitam karena dinilai tidak efisien atau lamanya penghasilan bagi para petani. Harga beras hitam di pasaran cukup tinggi dibanding beras khusus lain seperti beras putih atau beras merah (Hasil observasi lapang tidak dipublikasikan, 2017). PERMENTAN (2017) memasukkan beras hitam ke dalam kelas mutu beras khusus. Tampilan fisik ketiga jenis beras khus tersebut dapat dilihat berturut-turut pada Gambar 1 berikut ini.

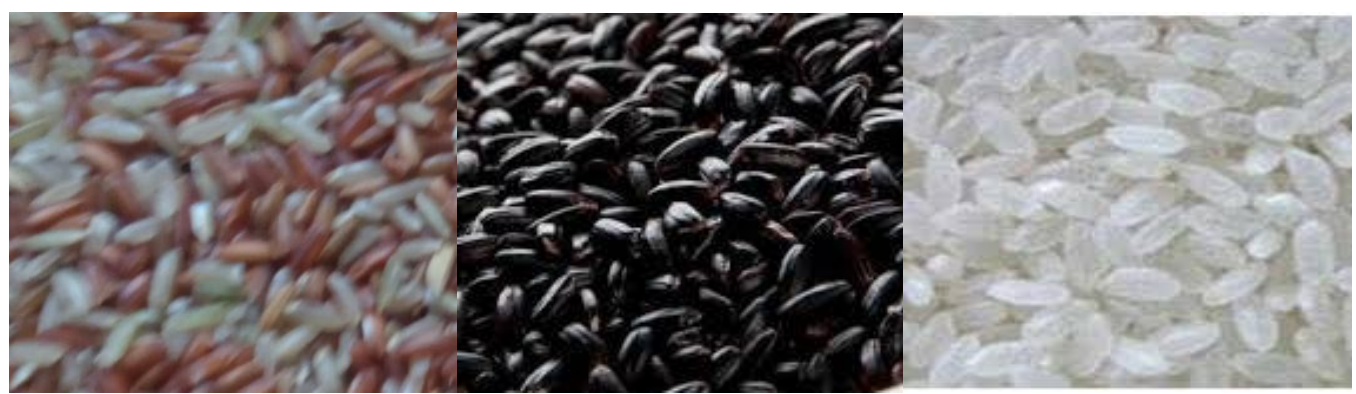

Gambar 1. Beras merah, beras hitam dan beras Pandanwangi.

Peran suatu produk dalam memenuhi kebutuhan konsumen dapat digantikan oleh produk lain dalam fungsi yang sama. Konsumen dapat dengan mudah beralih ke produk substitusi lainnya karena alasan tertentu, antara lain karena harga, kualitas, ketersediaan yang lebih memenuhi harapan konsumen.

Terdapat beberapa dimensi yang berpengaruh terhadap daya saing produk di antaranya: kuantitas, kualitas, harga (Roedhy Poerwanto (2009) dalam Mahdi, 2013), keamanan (Dinas Pertanian DIY, 2008), kontinyuitas pasokan (Landoala, 2013), ketepatan pengiriman dan kemampuan ditelusur. Pardamean (2014) mengatakan bahwa kuantitas adalah nilai perbedaan yang disebabkan oleh perbedaan unit penjualan dan jumlah perbedaan material dalam anggaran

Daya Saing Beras Pandanwangi, Beras Merah Dan Beras Hitam Di Wilayah Pemasaran Kabupaten Cianjur dengan unit realisasi penjualan dan jumlah material yang dianggarkan. Sementara itu yang dimaksud kualitas produk adalah segala atribut produk itu sendiri yang menjadi keunggulan dibandingkan produk sejenis lainnya.

\section{METODE PENELITIAN}

Penelitian ini dilaksanakan di wilayah pemasaran beras di kabupaten Cianjur. Dasar penentuan lokasi penelitian adalah mengingat Cianjur merupakan sentra produksi sekaligus penjualan beras Pandanwangi murni, beras merah dan beras hitam. Populasi dalam penelitian ini adalah para petani sebagai produsen beras

Pandanwangi, beras merah dan beras hitam yang sekaligus menggiling dan menjual berasnya serta pedagang beras di 
sejumlah gerai yang yang sudah beberapa tahun terakhir ini senantiasa menjual beras Pandanwangi murni, beras merah dan beras hitam sehingga sudah mengenal dengan baik karakteristik ketiga jenis beras tersebut. Dari populasi tersebut diharapkan akan diperoleh tanggapan petani dan pedagang beras mengenai daya saing beras pandanwangi murni, beras merah dan beras hitam. Jumlah petani dan atau pedagang beras di Kabupaten Cianjur tidak diketahui jumlahnya. Berdasarkan hal itu, maka perlu dilakukan sampling untuk menghemat waktu dan biaya (Subagyo, 2006; Sugiyono, 2011). Sampling yang dilakukan adalah non probability sampling dengan teknik quota sampling. Dalam penelitian ini jumlah sampel sebanyak 30 responden.
Pada penelitian ini, variabel yang dikaji adalah : kualitas, harga, ketersediaan. Variabel penelitian tidak dikelompokkan ke dalam variabel bebas dan variabel tergantung, karena hanya dikaji tingkat daya saing. Tingkat daya saing Kualitas diukur melalui indikator : kesesuaian produk dengan karakteristiknya, kehandalan produk, tingkat keawetan dan konsistensi produk dengan standar. Variabel Tingkat daya saing Harga diukur melalui indikator : keterjangkauan harga dan komparasi harga dengan produk di kelasnya. Variabel tingkat daya saing Ketersediaan diukur dengan : keberlanjutan pasokan dan ketersediaan jumlah yang dibutuhkan. Tanggapan responden diukur dengan skala Likert berperingkat atau ordinal dari skala 1 (sangat tidak setuju), 2 (tidak setuju), 3 (cukup), 4 (setuju) sampai 5 (sangat setuju).

Tabel 1. Operasionalisasi Variabel Penelitian.

\begin{tabular}{|c|c|c|c|}
\hline $\begin{array}{l}\text { Variabel } \\
\text { Penelitian }\end{array}$ & Konsep Variabel & Indikator & Skala \\
\hline Kualitas & $\begin{array}{l}\text { Kualitas produk ditentukan oleh } \\
\text { beberapa indikator diantaranya : } \\
\text { performance, } \\
\text { reliability, comformance,durability, serviceabili } \\
\text { ty, aesthetics, fit and finish (Pincen Gapery, } \\
\text { dalam Umar (2005) dalam Kusumawati } \\
\text { 2017). }\end{array}$ & $\begin{array}{l}\text { 1. Kesesuaiaan produk } \\
\text { dengan karakteristik } \\
\text { produk. } \\
\text { 2. Kehandalan dari produk } \\
\text { tersebut. } \\
\text { 3. Tingkat keawetan atau } \\
\text { ketahanan produk. } \\
\text { 4. Konsistensi produk untuk } \\
\text { menyamai standar yang } \\
\text { telah ditentukan. }\end{array}$ & Ordinal \\
\hline Harga & $\begin{array}{l}\text { Ada empat indikator yang } \\
\text { menciptakan sebuah harga yaitu: } \\
\text { Keterjangkauan harga, kesesuaiaan } \\
\text { kualitas harga terhadap produk, daya } \\
\text { saing hargadan kesesuiaan harga } \\
\text { dengan manfaat (Rosfita } 2010 \text { dalam } \\
\text { sagita } 2013 \text { dalam Kusumawati 2017). }\end{array}$ & $\begin{array}{l}\text { 1. Harga terjangkau oleh } \\
\text { konsumen. } \\
\text { 2. Harga berkomparasi } \\
\text { dengan beras khusus } \\
\text { lainnya. }\end{array}$ & Ordinal \\
\hline Ketersediaan & $\begin{array}{l}\text { Yang mrnjadi faktor penentu daya } \\
\text { saing produk yaitu : Keberlanjutan } \\
\text { pasokan atau ketersediaan produk, } \\
\text { kualitas dan harga ( Poerwanto } 2009 \\
\text { dalam Mahdi } 2015 \text {. }\end{array}$ & $\begin{array}{l}\text { 1. Keberlanjutan pasokan } \\
\text { beras. } \\
\text { 2. Tersedia dalam jumlah } \\
\text { yang dibutuhkan. }\end{array}$ & Ordinal \\
\hline
\end{tabular}

Rincian dari variabel-variabel tersebut dapat dilihat pada Tabel 1. mengenai operasinalisasi variabel penelitian. Tingkat Daya Saing produk beras Pandanwangi, beras merah dan beras hitam akan diukur melalui variabel Kualitas, Harga dan Ketersediaan. Untuk menjawab tujuan penelitian pertama yaitu mengetahui tingkat daya saing, dilakukan pengkategorian kelas tingkat daya saing.

Daya Saing Beras Pandanwangi, Beras Merah Dan Beras Hitam Di Wilayah Pemasaran Kabupaten Cianjur
Terdapat lima kelas tingkat daya saing dengan interval kelas dihitung melalui skor nilai tanggapan tertinggi yaitu 5 dikurangi skor nilai tanggapan terendah yaitu 1 . Selanjutnya nilai selisih tersebut dibagi dengan jumlah kelas yaitu lima. Hasil penghitungan diperoleh nilai sebesar 0.8 yang merupakan interval kelas. Sedangkan untuk menjawab tujuan penelitian ke dua, dilakukan pengujian hipotesis dengan 
uji T. Uji T digunakan untuk mengetahui signifikan tidaknya perbedaan daya saing antara beras Pandanwangi terhadap beras merah, beras Pandanwangi terhadap beras hitam dan antara beras hitam dengan beras merah.

\section{HASIL DAN PEMBAHASAN}

Pengumpulan data kuantitatif dilakukan terhadap 30 responden yang terdiri dari petani sekaligus penjual beras Pandanwangi di sejumlah toko penjual beras di kabupaten Cianjur. Karakteristik responden dalam penelitian ini meliputi : jenis kelamin, usia, tingkat pendidikan, stutusnya sebagai produsen atau pengecer dan lamanya berbisnis beras. Seluruh karakteristik tersebut dapat dijelaskan pada Tabel 2 berikut ini:

Tabel 2. Karakteristik Responden.

\begin{tabular}{lllll}
\hline No & Keterangan & Kategori & Jumlah & Persentase (\%) \\
\hline $\mathbf{1}$ & Jenis Kelamin & Laki-laki & 21 & 70 \\
& & Perempuan & 9 & 30 \\
\hline $\mathbf{2}$ & Usia & $<20$ & - & - \\
& & $20-30$ & 10 & 34 \\
& & $31-40$ & 10 & 33 \\
& & $41-50$ & 6 & 20 \\
& & $>50$ & 4 & 13 \\
\hline $\mathbf{3}$ & Tingkat Pendidikan & Tidak Tamat SD & 1 & 3 \\
& & SD & - & - \\
& & SMP & 10 & 34 \\
& & SMA & 19 & 63 \\
& & Diploma & - & - \\
& & Sarjana & - & - \\
\hline $\mathbf{4}$ & Apa posisi Bapak/Ibu sebagai & Pedagang (pengecer) & 20 & 67 \\
& produsen atau pengecer? & Produsen & & \\
& & & 10 & 33 \\
\hline $\mathbf{5}$ & Sudah berapa lama Bapak/Ibu & $>5$ Tahun & 20 & 67 \\
& berjualan beras khusus? & $>3$ Tahun & 5 & 17 \\
& & $>2$ Tahun & 5 & 16
\end{tabular}

Dari Tabel 2 dapat dilihat bahwa terdapat $70 \%$ responden adalah pria yang berada di jenjang usia produktif $20-50$ tahun sebanyak 87\%. Sebanyak $67 \%$ sebagai pengecer yang sudah berpengalaman menjual beras $>5$ tahun dan sebagian besar (63\%) berpendidikan SLTA. Keadaan ini menjelaskan bahwa responden didominasi oleh responden yang berprofesi sebagai pedagang pengecer beras dan banyak dilakukan oleh pria. Responden yang sebagian besar sudah berbisnis beras lebih dari lima tahun, menjadikannya dapat dijadikan sumber informasi mengenai tanggapannya akan kualitas, harga dan ketersediaan beras untuk menentukan tingkat daya saing beras.

Daya Saing Beras Pandanwangi, Beras Merah Dan Beras Hitam Di Wilayah Pemasaran Kabupaten Cianjur
Untuk menjawab tujuan penelitian pertama, data tanggapan responden dianalisis secara deskriptif terlebih dahulu untuk mengetahui tanggapan rata-rata responden terhadap faktor-faktor yang menentukan daya saing beras. Skor ratarata tanggapan dikategorikan ke dalam kelas kategori Sangat Setuju (4.2 - 5.0), Setuju (3.4 - 4.1), Kurang Setuju (2.6 3.3), Tidak Setuju $(1.8-2.5)$ dan Sangat Tidak Setuju $(1.0-1.7)$. Secara deskriptif dapat diketahui bahwa tanggapan responden terhadap kualitas, harga dan ketersediaan beras dapat diringkas pada tabel 3, 4 dan 5 berikut ini.

Dari tabel 3 dapat disimpulkan bahwa responden pada umumnya menyatakan sangat setuju bahwa beras 
Pandanwangi berkualitas dengan nilai skor rata-rata 4.28 (interval $4.2-5.0$ ). Indikator kualitas yang mendapatkan nilai skor tanggapan tertinggi adalah pada pernyataan bahwa beras Pandanwangi beraroma wangi khas dan nasinya tidak cepat basi. Responden hanya menyatakan setuju dengan nilai skor 3.98 (interval 3.4 - 4.1) bahwa harga beras Pandanwangi terjangkau oleh daya beli konsumen dan bersaing dengan beras merah dan beras hitam. Untuk daya saing ketersediaan, responden menyatakan setuju dengan nilai skor 3.80 (interval $3.4-4.1$ ).

Tabel 3. Rata-rata tanggapan responden terhadap beras Pandanwangi.

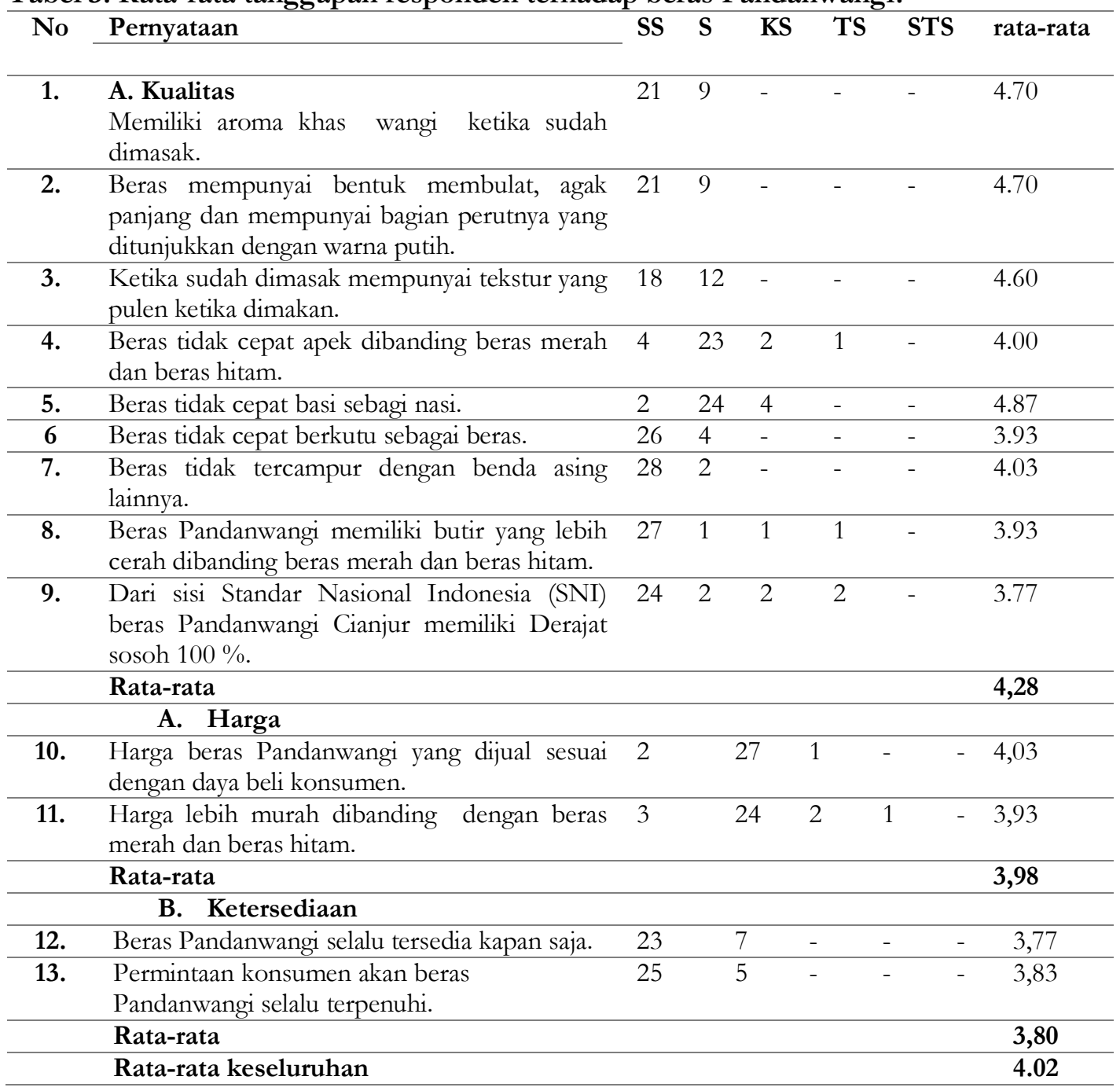

Untuk mengetahui tingkat daya saing antara beras Pandanwangi, beras merah dan beras hitam, maka nilai skor tanggapan responden direkapitulasi untuk diperbandingkan. Hasil rekapitulasi tersebut dapat dilihat pada Tabel 6. Pada Tabel 6 dapat diketahui bahwa untuk tanggapan terhadap kualitas, harga dan ketersediaan, beras Pandanwangi mendapatkan tanggapan tertinggi. Hal ini menjelaskan bahwa beras Pandanwangi

Daya Saing Beras Pandanwangi, Beras Merah Dan Beras Hitam Di Wilayah Pemasaran Kabupaten Cianjur memiliki tingkat daya saing dari segi kualitas, harga dan ketersediaan tertinggi dibandingkan dengan beras merah dan beras hitam. Peringkat ke dua dimiliki beras merah dan diikuti oleh beras hitam. Fakta di lapang, konsumen lebih menyukai beras Pandanwangi daripada beras merah dan beras hitam. Kesukaan konsumen dikarenakan beras Pandanwangi memiliki aroma wangi khas beras dan tekstur nasi yang pulen. 
Sementara itu, alasan konsumen mengkonsumsi beras merah dan beras hitam adalah untuk keperluan kesehatan. Beras merah dan beras hitam yang hanya diolah sampai dengan pecah kulit, kandungan seratnya cukup tinggi sehingga baik dikonsumsi oleh mereka yang mengurangi konsumsi karbohidrat dan lebih membutuhkan serat. Kelemahan dari ketiga jenis beras tersebut terletak pada ketersediaannya. Nilai skor tanggapan responden terhadap ketersediaan berada pada nilai skor terendah dibandingkan kualitas dan harga.
Tingkat ketersediaan beras hitam paling rendah dibandingkan dengan beras Pandanwangi dan beras merah. Pasokan beras hitam memang terbatas. Selain disebabkan tingkat permintaan yang rendah, pasokannyapun tidak sebanyak beras merah dan beras Pandanwangi. Rendahnya ketersediaan ketiga jenis beras tersebut di wilayah pemasaran Cianjur dikarenakan sebagian besar beras tersebut didistribusikan keluar kota Cianjur yaitu ke Bandung, Jakarta, Tangerang, Bekasi dan kota-kota lain di Jawa Barat

Tabel 4. Rata-rata tanggapan responden terhadap hitam.

\begin{tabular}{|c|c|c|c|c|c|c|c|}
\hline No & Pernyataan & SS & $\mathbf{S}$ & KS & TS & STS & Rata-rata \\
\hline \multicolumn{8}{|c|}{ A. Kualitas } \\
\hline 1. & $\begin{array}{l}\text { Memiliki aroma khas wangi ketika sudah } \\
\text { dimasak }\end{array}$ & 1 & 2 & 22 & 5 & - & 2.97 \\
\hline 2. & $\begin{array}{l}\text { Beras mempunyai bentuk membulat, agak } \\
\text { panjang dan mempunyai bagian perutnya yang } \\
\text { ditunjukkan dengan warna putih. }\end{array}$ & 1 & - & 25 & 3 & 1 & 2.00 \\
\hline 3. & $\begin{array}{l}\text { Ketika sudah dimasak mempunyai tekstur yang } \\
\text { pulen ketika dimakan. }\end{array}$ & 2 & 1 & 26 & 1 & - & 3.13 \\
\hline 4. & $\begin{array}{l}\text { Beras tidak cepat apek dibanding beras } \\
\text { Pandanwangi dan beras hitam. }\end{array}$ & 1 & 1 & 27 & 1 & - & 3.10 \\
\hline 5. & Beras tidak cepat basi sebagai nasi. & 2 & 1 & 26 & 1 & - & 3.13 \\
\hline 6. & Beras tidak cepat berkutu sebagai beras. & 1 & 2 & 26 & 1 & - & 3.10 \\
\hline 7. & $\begin{array}{l}\text { Beras tidak tercampur dengan benda asing } \\
\text { lainnya. }\end{array}$ & 2 & 2 & 24 & 2 & - & 3.13 \\
\hline 8. & $\begin{array}{l}\text { Beras hitam memiliki butir yang lebih cerah } \\
\text { dibanding beras Pandanwangi dan beras hitam. }\end{array}$ & 1 & 1 & 27 & 1 & - & 3.07 \\
\hline \multirow[t]{2}{*}{9.} & $\begin{array}{l}\text { Dari sisi Standar Nasional Indonesia (SNI) } \\
\text { beras merah memiliki Derajat sosoh } 100 \% \text {. }\end{array}$ & 1 & 3 & 22 & 4 & - & 3.07 \\
\hline & $\begin{array}{l}\text { Rata-rata } \\
\text { B. Harga }\end{array}$ & & & & & & 2.97 \\
\hline 10. & $\begin{array}{l}\text { Harga yang dijual sesuai dengan daya beli } \\
\text { konsumen. }\end{array}$ & 1 & 7 & 16 & 6 & - & 3.01 \\
\hline \multirow[t]{2}{*}{11.} & $\begin{array}{l}\text { Harga berbeda dibanding beras merah dan } \\
\text { Pandanwangi }\end{array}$ & - & 9 & 16 & 5 & - & 3.13 \\
\hline & $\begin{array}{l}\text { Rata-rata } \\
\text { C. Ketersediaan }\end{array}$ & & & & & & 3.07 \\
\hline 12. & Beras hitam selalu tersedia kapan saja. & 1 & 1 & 20 & 8 & - & 2.83 \\
\hline 13. & $\begin{array}{l}\text { Permintaan konsumen akan beras hitam selalu } \\
\text { terpenuhi. }\end{array}$ & 1 & 1 & 22 & 6 & - & 2.90 \\
\hline & Rata-rata & & & & & & 2.87 \\
\hline & Rata-rata keseluruhan & & & & & & 2.97 \\
\hline
\end{tabular}


Tabel 5. Rekapitulasi nilai skor tanggapan responden terhadap kualitas, harga dan ketersediaan.

\begin{tabular}{l|c|c|c}
\hline \multicolumn{1}{c|}{ Tingkat Daya Saing } & Beras Pandanwangi & Beras Merah & Beras Hitam \\
\hline Kualitas & 4.28 & 3.17 & 2.97 \\
\hline Harga & 3.98 & 3.02 & 3.07 \\
\hline Ketersediaan & 3.8 & 3.15 & 2.87 \\
\hline Rata-rata & 4.02 & 3.11 & 2.97 \\
\hline
\end{tabular}

Untuk menjawab tujuan penelitian ke dua, dilakukan pengujian hipotesis dengan uji T. Pengujian dilakukan dengan membandiingkan antara beras Pandanwangi dengan beras merah (Tabel 7), antara beras pandanwangi dengan beras hitan (Tabel 8) dan antara beras merah dengan beras hitam (Tabel
9). Hipotesis yang diuji adalah $\mathrm{H}_{0}$ : Tidak terdapat perbedaan signifikan tingkat daya saing antara dua jenis beras yang diperbandingkan dari segi kualitas, harga dan ketersediaan. $\mathrm{H}_{1}$ : Terdapat perbedaan signifikan tingkat daya saing antara dua jenis beras yang diperbandingkan dari segi kualitas, harga dan ketersediaan.

Tabel 6. Uji T antara beras Pandanwangi dengan beras merah.

\begin{tabular}{cccc}
\hline Variabel & T hitung & T tabel 0,005 & Hasil \\
\hline Kualitas & 0,000000000000034 & $<2,052$ & Terima $\mathrm{H}_{0}$ tolak $\mathrm{H}_{1}$ \\
\hline Harga & 0,00000116 & $<2,052$ & Terima $\mathrm{H}_{0}$ tolak $\mathrm{H}_{1}$ \\
\hline Ketersediaan & 0,000000116 & $<2,052$ & Terima $\mathrm{H}_{0}$ tolak $\mathrm{H}_{1}$ \\
\hline
\end{tabular}

Pada Tabel 7. Dapat dilihat bahwa $\mathrm{T}$ hitung untuk kualitas, harga dan ketersediaan lebih besar daripada $\mathrm{T}$ tabel pada tingkat kepercayaan 95\% dan menggunakan two tail test. Keadaan ini menjelaskan bahwa seluruh hipotesis nol diterima dan hipotesis satu ditolak. Hal ini berarti bahwa tidak terdapat perbedaan signifikan tingkat daya saing antara beras Pandanwangi dengan beras merah dalam hal kualitas, harga dan ketersediaan. Hasil ini tidak bertentangan dengan pengklasifikasian kelas mutu beras oleh Peraturan Menteri Pertanian Nomor 31/PERMENTAN//PP.130/8/2017.

Keduanya termasuk ke dalam kelas mutu beras khusus. Beras Pandanwangi sebagai beras Indikasi Geografis dan beras merah termasuk ke dalam beras untuk kesehatan.

Tabel 7. Uji T antara beras Pandanwangi dengan beras hitam.

\begin{tabular}{llll}
\hline Variabel & T hitung & T tabel 0,005 & Hasil \\
\hline Kualitas & 0,0000000000002 & $<2,052$ & Terima $\mathrm{H}_{0}$ tolak $\mathrm{H}_{1}$ \\
\hline Harga & 0,0000013 & $<2,052$ & Terima $\mathrm{H}_{0}$ tolak $\mathrm{H}_{1}$ \\
\hline Ketersediaan & 0,0000001 & $<2,052$ & Terima $\mathrm{H}_{0}$ tolak $\mathrm{H}_{1}$ \\
\hline
\end{tabular}

Hasil penelitian yang dapat dibaca dari Tabel 8 adalah bahwa antara beras Pandanwangi dengan beras hitam tidak ada perbedaan signifikan dalam tingkat daya saing kualitas, harga maupun ketersediaan. Hasil inipun membenarkan pengklasifikasian kelas mutu beras khusus oleh Permentan. Beras hitam dalam kelas mutu beras khusus termasuk ke dalam beras untuk kesehatan karena kandungan seratnya yang tinggi.

Tabel 8. Uji T antara beras merah dengan beras hitam.

\begin{tabular}{llll}
\hline Variabel & T hitung & T table & Hasil \\
\hline Kualitas & 0,332 & $<2,052$ & Terima $\mathrm{H}_{0}$ tolak $\mathrm{H}_{1}$ \\
\hline Harga & 0,329 & $<2,052$ & Terima $\mathrm{H}_{0}$ tolak $\mathrm{H}_{1}$ \\
\hline Ketersediaan & 0,521 & $<2,052$ & Terima $\mathrm{H}_{0}$ tolak $\mathrm{H}_{1}$ \\
\hline
\end{tabular}


Hasil uji $\mathrm{T}$ untuk membandingkan beras merah dengan beras hitampun menunjukkan hasil serupa seperti pada Tabel 9. Seluruh $\mathrm{H}_{0}$ diterima dan seluruh $\mathrm{H}_{1}$ ditolak. Hal ini berarti bahwa tidak terdapat perbedaan tingkat daya saing yang signifikan dalam hal kualitas, harga dan ketersediaan.

\section{KESIMPULAN}

Dari pembahasan di atas, dapat disimpulkan bahwa :

1. Tingkat daya saing antara beras Pandanwangi, beras merah dan beras hitam dari segi kualitas, harga dan ketersediaan berdasarkan tanggapan responden didapatkan bahwa tingkat daya saing tertinggi sampai dengan terendah berturut-turut adalah beras Pandanwangi, beras merah dan terakhir beras hitam. Nilai skor ratarata tanggapan responden berturutturut sebesar 4.02, 3.11 dan 2.97.

2. Dari hasil uji T diketahui bahwa tidak terdapat perbedaan tingkat daya saing yang signifikan dalam hal kualitas, harga dan ketersediaan baik antara beras pandanwangi dengan beras merah, antara beras Pandanwangi

\section{DAFTAR PUSTAKA}

Asmarani, Mufita. 2017. Analisis Adaptasi Padi Sawah Beras Merah yang Digogokan. Skripsi. Fakultas Pertanian. UNLA Bandar Lampung.

Badan Kependudukan dan Keluarga Berencana Nasional Direktorat Pelaporan dan Statistik. 2013. Profil Hasil Pendataan Keluarga 2012. Jakarta.

David, F. 2015. Strategic Management. Concept and Cases. 13 $3^{\text {th }}$ edition. Ebook. Prentice Hall, New Jersey.

Dinas Pertanian Tanaman Pangan Kabupaten Cianjur. 2009. Laporan Tahunan Kabupaten DT II. Cianjur.

Daya Saing Beras Pandanwangi, Beras Merah Dan Beras Hitam Di Wilayah Pemasaran Kabupaten Cianjur dengan beras hitam dan antara beras merah dengan beras hitam.

\section{SARAN}

1. Pemerintah daerah Cianjur sebaiknya lebih menggalakkan masyarakat Cianjur yang termasuk ke dalam rumah tangga III dan III+ untuk mau mengkonsumsi beras Pandanwangi sebagai beras IG Cianjur. Hal ini akan mendorong produksi dan pemasaran beras tersebut di wilayah Cianjur.

2. Bagi petani dan produsen beras Pandanwangi, beras merah maupun beras hitam, sebaiknya lebih memperluas dan menambah pasokannya ke toko-toko beras lainnya sehingga distribusi beras-beras tersebut lebih merata.

3. Untuk penelitian lanjutan, dapat dikaji besarnya pengaruh faktor-faktor penentu daya saing baik secara parsial maupun simultan terhadap daya saing ketiga jenis beras tersebut. Perlu juga dikaji ditambahkan indicator-indikator dari penentu daya saing agar lebih memberikan gambaran yang sebenarnya kondisi daya saing ketiga beras tersebut.

Dinas Pertanian Tanaman Pangan dan Hortikuktura Daerah Istimewa Yogyakarta. 2008. Laporan Tabunan Kabupaten DT $I$. Yogyakarta.

Sa`adah, I.R., Suprianta, Subejo. 2013. Keragaman Warna Gabah dan warna Beras Varietas Lokal Padi Beras Hitam (Oryza Sativa L.) yang Dibudidayakan Oleh Petani Kabupaten Sleman, bantul Dan Magelang. Jurnal Vegetalika Vol.2, No.3.

Tan, Pricillia; Nelly M. dan Shierly K. 2016. Gambaran aktivitas dan stabilitas antioksidan ekstrak beras hitam (Oryza sativa L.) kultivar Enrekang Sulawesi Selatan. 
Kusumawati, S. 2017. Faktor-Faktor yang Mempengaruhi Daya Saing Produk Sayuran Gapoktan Multi Tani Jaya Giri. Skripsi. Fakultas Sains Terapan Universitas Suryakancana Cianjur.

Landaola, T. 2013. Potensi Pertanian Terhadap Pertumbuhan Ekonomi Indonesia.

http://jembatan4.blogspot.co.id/ 2013/07/potensi-pertanianterhadap-pertumbuhan.html.

MP3C. 2015. Buku Persyaratan Persyaratan Permohonan Pendaftaran Indikasi Geografis Beras Pandanwangi Cianjur. Direktorat Jenderal Hak Kekayaan Intelektual. Jakarta.

Pardamean. 2014. Mengelola Kebun dan Pabrik Kelapa Sawit Secara Profesional. . Jakarta Timur :PT. Penebar Swadaya.

Peraturan Menteri Pertanian Republik Indonesia. 2017. Kelas Mutu Beras. No. 31/PERMENTAN/PP.130/8/2 017. Jakarta.
Pemerintah Daerah Jawa barat. 2012. Indikator Kesejahteraan Jawa Barat. Bandung.

Purwono, J.,S. Sugyaningsih, A. Priambudi. 2013. Analisis Tata Niaga Beras Di Kecamatan Rogojampi Kabupaten Banyuwangi. Jurnal $\mathrm{NeO}-\mathrm{Bis}$. Vol.7.No.2.

Mahdi, Rizal. 2013. Pertanian Masa Depan. http://rizalm09.student.ipb.ac.id $/$ pertanian-ku/.

Subagyo, P. 2006. Statistik Induktif. Yogyakarta :BPFE.

Sugiyono, 2011. Metode Penelitian Kuantitatif Kualitatif Dan R\&D. Bandung :Alfabeta.

Sugiyono, 2009. Memahami Penelitian Kualitatif. Bandung:Alfabet.

Undang - Undang No.18, 2012. Pangan. Presiden Republik Indonesia dengan persetujuan Dewan Perwakilan Rakyat Republik Indonesia. 